\title{
Pengaruh Pengelolaan Kelas Dalam Pelajaran Agama Kristen Terhadap Prestasi Belajar Siswa Di SMP Kanaan Ungaran Tahun Ajaran 2017-2018
}

\author{
Markus Oci \\ 1) Dosen Sekolah Tinggi Teologi Kanaan Nusantara \\ *) Penulis korespondensi: markus.oci@ gmail.com
}

Received: 6 Dec 2018 / Revised: 21 Dec 2018 / Accepted: 26 Dec 2018

\begin{abstract}
Abstrak
Pengelola kelas yang merupakan tugas guru dalam menciptakan suasana kelas yang memungkikan terjadinya interaksi pembelajaran semaksimal mungkin, meningkatkan, memperbaiki belajar siswa sehingga tetap tertarik terlibat dalam kegiatan belajar mengajar dan lebih mudah dalam menerima pelajaran. Pengelola kelas merupakan ketrampilan yang harus dimiliki guru dalam memahami, mendiagnosis, dan kemampuan bertindak menuju perbaikan suasana kelas terhadap aspek-aspek manajemen kelas. Belajar merupakan proses perubahan, dan perubahan dapat lihatkan dalam bentuk peningkatan kualitas dan kuantitas tingkah laku, dan belajar dari sisiwa tersebut. Berdasarkan hasil penelitian bahwa persamaan regresi yang yang di dapat adalah $\mathrm{Y}=$ $20,393+0,601 \mathrm{X}$, dimana: $\mathrm{Y}=$ prestasi belajar siswa, $\mathrm{X}=$ pengaruh pengelolaan kelas. Artinya koefisien regresi sebesar 0, 601 atau 60, 1\% menyatakan bahwa setiap perubahan Pengelolaan kelasakan meningkatkan Prestasi Belajar Siswa di Sekolah Menengah Pertama Kanaan Ungaran sebesar $60,1 \%$. Sebaliknya, bila pengelolaan kelas
\end{abstract}


$100 \%$, maka prestasi belajar siswa juga diprediksikan mengalami penurunan sebesar $60,1 \%$. Koefisien korelasi pengaruh antara kedua variabel adalah 0,522 . Artinya tingkat pengaruh menunjukkan adanya hubungan yang sedang antara variabel $\mathrm{X}$ terhadap variabel $\mathrm{Y}$. Hubungannya adalah positif, sebab pada angkat 0,522 tidak ada tanda negatif. Oleh karena itu, semakin besar pengelolaan kelas, maka semakin meningkat prestasi belajar siswa sedangkan pengaruh positif yang signifikan antara pengelolaan kelas terhadap prestasi belajar siswa.

Kata Kunci : Pengelola Kelas, Tugas Utama Guru Dalam Kegiatan Belajar Mengajar.

\begin{abstract}
Class managers who are the teacher's task in creating a classroom atmosphere that allows the interaction of learning to be as much as possible, improve, improve student learning so that they remain interested in being involved in teaching and learning activities and easier to receive lessons. Class manager is a skill that must be possessed by the teacher in understanding, diagnosing, and the ability to act towards improving the classroom atmosphere towards aspects of class management. Learning is a process of change, and change can be seen in the form of improving the quality and quantity of behavior, and learning from the student. Based on the results of the study that the regression equation that is obtained is $\mathrm{Y}=20,393+0,601 \mathrm{X}$, where: $\mathrm{Y}=$ student learning achievement, $\mathrm{X}=$ class management influence. This means that the regression coefficient of 0,601 or $60,1 \%$ states that each change in class management will improve Student Learning Achievement at Ungaran Canaan Middle School by $60.1 \%$. Conversely, if the management of the class is $100 \%$, then student achievement is also predicted to decline by $60.1 \%$. The influence correlation coefficient between the two variables is 0,522 . This means that the level of influence indicates a moderate relationship between variable $X$ to variable Y. The relationship is positive, because at lift 0,522 there is no negative sign. Therefore, the greater the classroom management, the more students' learning achievement increases while the significant
\end{abstract}


positive influence between classroom management on student learning achievement.

Keywords: Class Manager, Teacher's Main Task in Teaching and Learning Activities.

\section{Pendahuluan}

Sebagai suatu lembaga pendidikan format, sekolah harus mengembangkan potensi-potensi yang dimiliki siswa dalam kegiatan belajar mengajar. Untuk mencapai kegiatan belajar mengajar kreaktif dan inovatif guru memiliki peran yang sangat sentral kemudian guru harus mampu menciptakan suasana pembelajaran efektif, menyenangkan, serta terciptanya suasana pembelajaran yang kondusif, sehingga terdapat interaksi belajar mengajar yang berjalan dengan baik dan tujuan pembelajaran. Guru sebagai motor penggerak dalam kegiatan belajar mengajar harus mampu mengoptimalkan segala hal yang berhubungan dengan kegiatan belajar mengajar Guru merupakan pemegang peranan utama dalam proses belajar. Kegiatan belajar mengajar merupakan suatu proses yang mengandung serangkaian perbuatan guru dan siswa atau dasar hubungan timbal balik yang berlangsung dalam situasi edukatif untuk mencapai tujuan. Guru sebagai pengelola kegiatan belajar mengajar dan sebagai fasilitator, inisiator dan kreator harus mampu menciptakan kondisi belajar-mengajar yang efektif dalam kegiatan belajar mengajar, serta mampu mengembangkan segala hal-hal yang berkaitan dengan kegiatan belajar mengajar tersebut.

Pengelolaan kelas merupakan tugas utama guru dalam menciptakan suasana kelas yang terjadinya interaksi pembelajaran semaksimal mungkin, meningkatkan dan memperbaiki belajar sehingga siswa tetap tertarik dan terlibat dalam kegiatan belajar mengajar. Dengan kata lain siswa dapat belajar dengan baik dalam suasana yang wajar, tanpa tekanan dalam kondisi yang merangsang untuk belajar. Untuk menciptakan suasana yang dapat menumbuhkan digairah belajar, menigkatkan prestasi belajar siswa, dan lebih dalam belajar, maka 
diperlukan pengorganisasian kelas yang memadai. ${ }^{1}$ Kemampuan seorang guru dalam mengelola kelas merupakan bagian dari pengelolaan sekolah yang ikut menentukan mutu pendidikan. Kemampuan seorang guru dalam pengelolaan kelas, memiliki peranan yang sangat sentral, baik sebagai perencana, pelaksana, maupun evaluator pembelajaran.

Pengelolaan kelas merupakan tugas utama guru dan wali kelas dalam menciptakan suasana kelas yang memungkikan terjadinya interaksi pembelajaran semaksimal mungkin, meningkatkan, memperbaiki belajar siswa sehingga tetap tertarik terlibat dalam kegiatan belajar mengajar dan lebih mudah dalam menerima pelajaran, keberhasilan pengajaran dalam arti tercapainya tujuan-tujuan pengajaran sangat tergantung pada kemampuan mengatur kelas yang dapat menciptakan situasi yang memungkinkan anak didik dapat belajar, sehingga merupakan titik awal keberhasilan pengajaran. Siswa dapat belajar dengan baik dalam suasana yang wajar, tanpa tekanan dalam kondisi yang merangsang untuk belajar. Guru yang baik senantiasa mempersiapkan diri, merencanakan bahan pengajaran yang akan diajarkan. Adapun aspek-aspeknya ialah: Merumuskan tujuan, penyusunan alat evaluasi, menganalisis pokok pelajaran, berdasarkan tujuan pengajaran. Kemudian penyusunan program pengajaran berdasarkan pokok-pokok pelajaran untuk mencapai tujuan. Melaksanakan program dan evaluasi untuk menentukan apakah tujuan pengajaran tercapai atau tidak."

Untuk mencegah timbulnya tingkah laku tingkah siswa yang mengganggu kegiatan belajar mengajar, guru harus berusaha mendayagunakan potensi kelas, memfokuskan perhatian kepada peserta didik, memahami mereka secara induvidual dan memberi pelayananpelayanan tertentu yang merupakan wujud dukungan dari warga sekolah. Upaya-upaya yang dilakukan ini merupakan usaha dalam menciptakan kondisi belajar yang kondusif, optimal, dan menyenangkan agar proses pembelajaran dapat berjalan secara efektif dan efisien, sehingga tujuan pembelajaran prestasi dapat dicapai dengan maksimal.

${ }^{1}$ Cony Semiawan. 1990. Pendekatan Keterampilan Proses (Jakarta: Gramedia), 63.

${ }^{2}$ Ibid, 39-41. 
Suharsimi Arikunto yang dikutip oleh Syaiful Bahari Djamarah berpendapat bahwa: Pengelolaan kelas adalah suatu usaha yang dilakukan oleh penanggung jawab kegiatan belajar mengajar atau yang membantu dengan maksud agar dicapai kondisi optimal sehingga dapat terlaksana kegiatan belajar seperti yang diharapkan. Suharsimi memahami pengelolaan kelas ini dari dua segi, yaitu pengelolaan yang menyangkut siswa, dan pengelolaan fisik (ruangan, perabot, alat pelajaran). ${ }^{3}$ Pengelolaan kelas adalah suatu kegiatan tingkah laku yang sangat kompleks, dimana guru dituntut dapat mengembangkan dan mengelola kelas dengan semaksimal. Mengelolaan dalam dijabarkan sebagai berikut:

a) Meningkatkan pembelajaran

b) Meningkatkan prestasi belajar siswa dalam belajar

c) Menerapkan pendekatan belajar kreaktif, variatif, dan inovatif

d) Menjali interaksi antara guru dengan peserta didik

e) Membuat kontrak belajar dengan peserta didik." ${ }^{4}$

Kemudian indikator mengelolaan kelas yang baik, adalah:

a) Kondisi belajar yang optimal, kondisi belajar yang nyaman, tenang, sejuk sehingga sangat membantu perhatian siswa pada materi pelajaran.

b) Menunjukan sikap tanggap, perilaku positif atau negatif yang muncul didalam kelas harus dapat disikapi dengan baik sehingga dapat meningkatkan motivasi belajar siswa.

c) Memusatkan perhatian kelompok, dengan memusatkan perhatian secara terus menerus terhadap siswa dapat mempertahankan konsentrasi siswa di sebabkan oleh ketidakpahaman siswa terhadap arah dan sasaran yang akan dicapai.

d) Memberikan petunjuk dan tujuan yang jelas, sering terjadi kurangnya konsentrasi siswa disebabkan oleh ketidak pahaman siswa terhadap arah dan sasaran yang akan dicapai.

\footnotetext{
${ }^{3}$ Ibid., 177.

${ }^{4}$ Iskandar. 2009. Psikologi Pendidikan. (Cipayung. Ciputat: Gaung Persada), 210.
} 
e) Memberikan teguran dan penguatan, untuk mengarahkan tingkah laku siswa, dan penguat perlu dilakukan untuk memberikan respon positif dengan cara memberikan pujian dan penghargaan. ${ }^{5}$

Pengelolaan kelas adalah merupakan kegiatan yang berupa menciptakan dan mempertahankan kondisi yang optimal bagi terjadinya proses belajar mengajar. Kemudian dalam mengelolaan kelas ini termasuk pula menertibkan peserta didik yang melakukan berbagai kegiatan yang tidak ada hubungannnya dengan kegiatan belajar mengajar, atau suatu kegiatan yang mengganggu jalannya kegiatan belajar mengajar. Mengelolaan kelas adalah "keterampilan guru untuk menciptakan dan memeliharan kondisi belajar yang optimal, dan mengendalikannya bila terjadi gangguan dalam proses belajar. Dengan kata lain, ialah kegiatan-kegiatan untuk menciptakan dan mempertahankan."6 Mengelolaan kelas menurut Ahmad Rohani adalah menunjuk kepada kegiatan-kegiatan yang menciptakan dan mempertahankan kondisi yang optimal bagi terjadinya proses belajar (pembinaan "rapori", penghentian tingkah laku peserta didik yang menyelewengkan perhatian kelas. Ada beberapa faktor-faktor yang biasanya mempengaruhi pengelolaan kelas, yakni :

Pertama: Lingkungan belajar

Lingkungan belajar adalah segala sesuatu yang berhubungan dengan tempat proses pembelajaran dilaksanakan. Lingkungan ini mencakup tiga hal utama: ${ }^{7}$

\section{Lingkungan fisik}

Lingkungan fisik mampu memberi peluang gerak dan segala aspek yang berhubungan dengan upaya penyegaran pikiran bagi siswa setelah mengikuti proses pembelajaran yang sangat membosankan. Lingkungan fisik ini meliputi sarana-prasarana yang cukup dan memadai untuk proses pembelajaran secara tuntas dipastikan dapat membawa siswa pada kondisi pembelajaran yang kondusif.

${ }^{5}$ Syaiful Bahari Djamarah dan Aswan Zain. 2006. Strategi Belajar Mengajar. (Jakarta: Rineka Cipta), 187-190.

${ }^{6}$ Abdin Nata. 2009. Prespektif Islam Tentang Strategi Pembelajaran.

(Jakarta: Prenada Media Grroup), 264.

${ }^{7}$ Muhammad Saroni. 2006. Manajemen Sekolah-Kiat Menjadi Pendidik yang Kompeten (Jakarta: Ar-Ruzz), 82. 


\section{Lingkungan sosial}

Lingkungan sosial berhubungan dengan pola interaksi antar personil yang ada dilingkungan sekolah secara umum. Lingkungan sosial yang kondisif dalam hal ini, misalnya adanya keakraban yang proporsional antra guru dan siswa dalam pembelajaran.

\section{Lingkungan budaya}

Lingkungan budaya merupakan suatu kondisi pola kehidupan yang sesuai dengan pola kehidupan pada warganya, yakni siswa. ${ }^{8}$ Siswa adalah pribadi yang masih lebih dan massih membutuhkan proses adaptasi untuk setiap lingkungan dimana siswa berada. Untuk menciptakan kondisi pembelajaran yang kondusif, maka yang terutama harus dilakukan adalah menyamakan persepsi dan pola pikir tentang pola pergaulan.

\section{Kedua: Sikap Terhadap Belajar}

Sikap merupakan kemampuan memberikan penilaian tentang sesuatu yang membawa diri sesuai dengan penilaian. Adanya penilaian mengakibatkan terjadinya sikap menerima, menolak, atau belajar tesebut. Hal ini berpengaruh pada perkembangan kepribadian. Oleh karena itu siswa mempertimbangkan dari akibat sikap terhadap belajar. ${ }^{9}$ Sikap siswa terhadap kebutuhan belajar merupakan pertimbangan yang diperhitungkan oleh siswa itu sendiri. Seberapa besar siswa dapat menerima atau menolak dirinya untuk belajar. Jika siswa itu menolak atau masih menunda waktu belajar, maka hal ini masalah yang mengganggu proses belajar.

\section{Ketiga: Motivasi belajar}

Motivasi belajar merupakan kekuatan mental yang mendorong terjadinya proses belajar pada diri siswa perlu diperkuat terus menerus. Agar siswa memiliki motivasi belajar yang kuat pada tempatnya diciptakan suasana belajar yang menggembirakan. Motivasi siswa mengikuti proses pembelajaran merupakan faktor keberhasilan

${ }^{8}$ Ibid., 93

${ }^{9}$ Dimiyati dan Mudjiono. 2006. Belajar dan Pembelajaran (Jakarta: Rineka Cipta), 239. 
belajarnya. Jika siswa tidak semangat untuk mengikuti pelajaran, hal ini, juga menjadi yang harus ditangani.

Ketiga: Konsentrasi belajar

Merupakan kemampuan memusatkan perhatian pada pelajaran, yang tertuju pada isi bahan belajar maupun proses memperolehnya. ${ }^{10}$ Materi pelajaran yang dibahas di kelas diperoleh dengan baik, apa bila siswa mampui merekam materi itu untuk disimpan di otak. Siswa memikirkan sesuatu selain bahan materi di kelas itu, dapat mengganggu konsentrasi belajarnya.

Kempat: Mengolah bahan belajar

Mengolah bahan belajar merupakan kemampuan siswa menerima isi dan cara memperoleh ajaran sehingga menjadi bermakna bagio siswa. Kemampuan ini, bila siswa mengolah bahan menjadi semakin baik dan berpeluang aktif belajar. Jadi mengolah bahan ajaran dan pemerolehannya ini membutuhkan konsentrasi belajar.

Kelima: Menyimpan perolehan hasil belajar

Menyimpan perolehan hasil belajar merupakan kemampuan menyimpan isi dan cara perolehan pesan. Kemampuan menyimpan pesan tersebut dapat berlangsung dalam waktu pendek.

Tujuan pengelolaan kelas pada hakekatnya adalah bagian satuan pendidikan. Sudirman N. pengelolaan kelas adalah penyediaan fasilitas berbagai macam-macam kegiatan belajar siswa dalam lingkukan sosial, emosional, dan intelektual dalam kelas. Fasilitas yang disediakan itu memungkinkan siswa belajar dan bekerja, terciptanya suasana sosial yang memberikan kepuasan, suasana displin, perkembangan intelektual, emosional dan sikap dan serta apresiasi pada siswa. ${ }^{11}$

\section{Prestasi Belajar}

Prestasi Belajar terkadang disama artikan dengan hasi belajar. Berdasarkan suku kata, Prestasi dan Belajar memiliki makna yang

\footnotetext{
${ }^{10}$ Ibid., 238.

${ }^{11}$ Ibid., 178.
} 
berbeda dan saling berkaitan erat. Pada umumnya prestasi akan muncul setelah melakukan sebuah pembelajaran. Setiap proses pembelajaran akan menghasilkan prestasi belajar hanya saja sangat berbeda dari segi kualitas dan kuantitas untuk setiap individu yang melakukan kegiatan belajar. Prestasi belajar adalah hasil yang dicapai oleh seseorang setelah ia melakukan perubahan belajar, baik disekolah maupun diluar sekolah. Di dalam Webster's New Internasional Dictionary mengungkapkan tentang prestasi yaitu: "Achievement test a standardised for measuring the skill or knowledge by person in one more lines of work a study".

Mempunyai arti kurang lebih prestasi adalah standat test untuk mengukur kecakapan atau pengetahuan bagi seseorang didalam ssatu atau lebih dari garis-garis pekerjaan atau belajar. Dalam Kamus Populer prestasi belajar. Prestasi akan dihasilkan selama seseorang melakukan sesuatu kegiatan. Narsun Harapan beserta kawan-kawan memberikan batasan, bahwa prestasi adalah penilaian pendidikan tentang perkembangan dan kemajuan murid yang berkenan dengan penguasan bahan pelajaran yang disajiakan kepada mereka serta nilai-nilai yang terdapat dalam kurikulum. Menurut Syaiful Bhari Djamarah prestasi adalah hasil dari sebuah kegiatan yang telah dikerjakan, diciptakan, baik secara individual maupun kelompok.

Peserta dapat diartikan penilaian dari hasil kegiatan pendidikan tetang perkembanagan dan kemajuan murid yang berkenan dengan penguasaan bahan pelajaran dan nilai-nilai yang terdapat dalam kurikulum. Sedangkan pengertian belajar secara psikologis menurut Slameto merupakan proses perubahan tingkah laku sebagai hasil interaksi dengan lingkunagnnya dengan memenuhi kebutuhan hidupnya. Belajar adalah suatu proses usaha yang dilakukan individu untuk memperoleh suatu perubahan tingkah laku yang baru secara keseluruhan. Sebagai hasil pengalaman individu itu sendiri dalam interaksi dengan lingkungnnya. ${ }^{12}$ Pengertian "prestasi'dan“ belajar". Prestasi belajar adalah hasil yang diperoleh berupa kesaan-kesan yang mengakibatkan perubahan dalam diri individu sebagai hasil dari aktivitas dalam belajar.

12 Slameto. 1988. Belajar dan Faktor-Faktor yang Mempengaruhinya (Jakarta: Bina Aksara), 2 


\section{Pengertian Siswa}

Sistem penilaian merupakan suatu prosedur dan kriteria-kriteria penilain yang diberlakukan sekolah untuk menetapkan tingkat ketuntasan belajar dan kenaikan kelas peserta didik. Sistem penilaian itu berfungsi untuk mengendalikan proses dan hasil belajar, prestasi belajar dalam mengimplementasikan kurikulum. Kemampuan sumber daya pendukung dalam penyelenggaraan pembelajaran pada masing-masing sekolah. Semakin baik sumber merupakan sumber daya manusia dalam konteks siswa, semakin tinggi tingkat keefektifan pembelajaran. Pertimbangan daya dukung sekolah dalam menetapkan ketuntas kegiatan mengajar (KKM), hal ini didasarkan pada tingkat ketersediaan tenaga pendidikan, fasilitas yang tersedia, sarana dan prasarana pendidikan yang sangat dibutuhkan, biaya operasional pendidikan, manajemen sekolah, kepedulian dan stakeholder sekolah. Semakin tinggi tingat ketercukupan dan kesesuaian faktor dukung, maka semakin mudah untuk mencapai hasil belajar, sehingga nilanya sangat baik atau tinggi. Semakin rendah ketercukupan akan mempergaruhi daya dukung sekolah, maka semakin sulit untuk dapat dicapai hasil belajar yang ditetapkan, sehingga rata-rata nilanya sangat rendah.

\section{Prestasi Belajar Siswa Pendidikan Agama Kristen}

Belajar merupakan semua aktivitas mental yang berlangsung dalam interaksi aktif dalam lingkungan, yang menghasilkan perubahanperubahan dalam pengelolaan pemahaman, belajar adalah "berusaha memperoleh pengalaman". ${ }^{13}$ Sedangkan menurut Moh. Surya, “ definisi belajar adalah suatu proses usaha yang dilakukan individu untuk memperoleh suatu perubahan tingkah laku yang baru keseluruhan, sebagai hasil pengalaman individu itu sendiri dalam interaksi dengan lingkungan."14 Kesimpulan yang diambil dari kedua pengertian di atas, bahwa pada prinsipnya, belajar adalah perubahan diri seseorang. Belajar menurut Borton "merupakan perubahan tingkah laku pada diri individu dan individu dengan lingkungan sehingga mereka dapat berintraksi

${ }^{13}$ Abubakar, Sitti, Rahmaniar. 2007. Belajar dan Pembelajaran (Kendari: UNHALU), 89.

${ }^{14} \mathrm{http}$ ///belajar psikologi.com/pengertian-belajar-menurut-ahli Diakses di Ungaran 23 Mei 2018. 
dengan lingkungan."15 Jadi belajar merupakan proses perubahan, dan perubahan itu di perlihatkan dalam bentuk peningkatan kualitas dan kuantitas tingkah laku, dan belajar terjadi secara langsung atau mengalami langsung, sehingga terjadi perubahan seperti, ada pengikatan pengetahuan, ada usulan pemecahan baru untuk masalah yang diperkirakan akan terjadi. Belajar diartikan sebagai tahapan aktivitas yang menyebabkan terjadinya perubahan perilaku dan mental yang realif sebagai bentuk respon terhadap situasi dan interaksi dengan lingkungan.

E.G. Homrighausen mengatakan: "Pendidikan Agama Kristen berpangkal pada persekutuan umat Tuhan. Dalam Perjanjian Lama pada hakekatnya dasar-dasar terdapat pada sejarah suci purbakala, bahwa Pendidikan Agama Kristen itu mulai sejak terpanggilnya Abraham menjadi nenek moyang umat pilihan Tuhan, bahkan bertumbuh pada Allah sendiri karena Allah menjadi peserta didik bagi umat-Nya."16 Warner C. Graedorf Pendidikan Agama Kristen adalah "Proses pengajaran dan pembelajaran yang berdasarkan Alkitab, berpusat pada Kristus, dan bergantung kepada Roh Kudus, yang membimbing setiap pribadi pada semua tingkat pertumbuhan melalui pengajaran masa kini ke arah pengenalan dan pengalaman rencana dan kehendak Allah melalui Kristus dalam setiap aspek kehidupan, dan melengkapi mereka bagi pelayanan yang efektif, yang berpusat pada Kristus sang Guru Agung dan perintah yang mendewasakan pada murid." 17

Dampak pengelolaan kelas terhadap pencapaian hasil yang diharapkan, menurut Sudirman, dalam pemilihan metode mengajar harus mengandung dampak langsung dan dampak penyertaan/pengiring. ${ }^{18}$ Pendekatan pengelolaan kelas sebagai bagian dari proses dalam kegiatan pembelajaran Pendidikan Agama Kristen memiliki efek atau dampak

${ }^{15}$ Anurahman. 1985. Belajar dan Pembelajaran (Jakarta: Kedokteran EGC),

10.

${ }^{16}$ E.G.Homrighausen. 1985. Pendidikan Agama Kristen (Jakarta: BPK Gunung Mulia), 112.

${ }^{17}$ Paulus Lilik Kristanto. 2010. Prinsip dan Praktek Pendidikan Agama (Yogyakarta : Andi Offset), 4.

${ }^{18}$ N.A. Ametembun. 1987. Pendidikan Kurikulum Program Pengajaran Efek Intruksional dan Pengiring CBSA Metode Mengajar Media Pendidikan Pengelolaan Kelas dan Evaluasi Hasil Belajar (Bandung: Remaja Karya), 92. 
terhadap peningkatan prestasi belajar, baik dampak langsung maupun dampak tidak langsung. Prestasi atau keberhasilan belajar ini bukanlah semata-mata keberhasilan dari segi kognitif dan psikomotorik saja, tetapi mesti melalui aspek-aspek lain, seperti aspek efektif. Pengevaluasian satu aspek saja akan menyebabkan pengajaran kurang memiliki makna yang bersifat komprehensif. Ketiga aspek ini merupakan unsur-unsur pendukung hasil atau prestasi belajar pendidikan Agama Kristen. Dikatakan terdiri dari berbagai aspek pendukung, sebab kalau kita kembalikan pada istilah Pendidikan itu sendiri sangat kompleks yaitu meliputih seluruh pembahasan tingkah laku, baik cita, rasa, dan karsa, terutama dalam bidang Agama (Mata Pelajaran Pendidikan agama Kristen), yang didalamnya banyak mengandung unsur bimbingan moral.

\section{Metode Penelitian}

Metodologi Penelitian yang digunakan dalam penelitian ini adalah Ancangan Positivis atau Kuantitatif. Waktu penelitian ini dilaksanakan pada Maret 2017 Tahun Ajaran 2017/2018. Populasi adalah seluruh siswa SMP Kanaan Kelas VII-IX, yang terdiri dari 33 orang mahasiswa. Sampel digunakan pada penelitian ini terdiri 30 orang siswa. Teknik pengumpulan data melalui tahap-tahap, sebagai beriku: (1) Mendesain lembaran pengamatan dan angket sebagai alat pengumpulan. (2) Menyebarkan angket atau kuesioner yang ditujukan kepada responden yang akan diteliti yaitu semua seluruh siswa SMP Kanaan Kelas VII-IX. (3) Menghitung data hasil wawancara dan angket.

\section{Hasil Penelitian}

Deskripsi data hasil penelitian ini dikelompokkan menjadi dua variabel, yang terdiri: data variabel bebas tentang pengaruh pengelolaan kelas Mata Pelajaran Pendidikan Agama Kristen (x), sedangkan variabel terikat Prestasi belajar siswa (y).

a. Hasil penelitian variabel bebas (x) pengelolaan kelas dalam mata Pelajaran Pendidikan Agama Kristen Terhadap Prestasi Belajar Siswa. 
Tabel 1

Kondisi belajar yang optimal (X1)

\begin{tabular}{|l|c|c|r|r|}
\hline \multicolumn{1}{|c|}{ Kategori } & Frequency & Percent & \multicolumn{1}{c|}{$\begin{array}{c}\text { Valid } \\
\text { Percent }\end{array}$} & $\begin{array}{c}\text { Cumulative } \\
\text { Percent }\end{array}$ \\
\hline Ragu-ragu & 1 & $3,3 \%$ & 3,3 & 3,3 \\
\hline Setuju & 8 & $26,7 \%$ & 26,7 & 30,0 \\
\hline sangat setuju & 21 & $70,0 \%$ & 70,0 & 100,0 \\
\hline Total & 30 & 100,0 & 100,0 & \\
\hline
\end{tabular}

Sumber: Data primer yang d olah tahun 2018 berdasarkan SPSS 23

Berdasarkan data diatas, dapat diketahui bahwa semua responden sepakat menyatakan sangat setuju 56,7 \% dan setuju 33,3\% bahwa kondisi belajar Optimal guru harus selalu siap untuk mengajar, sedangkan sisanya yaitu $6,7 \%$ menyatakan ragu-ragu dan 3,3\% menyatakan tidak setuju.

Tabel 2

Sikap tanggap terhadap siswa $(\mathrm{X} 2)$

\begin{tabular}{|l|c|c|r|r|}
\hline \multicolumn{1}{|c|}{ Kategori } & Frequency & Percent & \multicolumn{1}{c|}{$\begin{array}{c}\text { Valid } \\
\text { Percent }\end{array}$} & $\begin{array}{c}\text { Cumulative } \\
\text { Percent }\end{array}$ \\
\hline tidak setuju & 1 & $3,3 \%$ & 3,3 & 3,3 \\
\hline ragu-ragu & 1 & $3,3 \%$ & 3,3 & 6,7 \\
\hline Setuju & 12 & $40,0 \%$ & 40,0 & 46,7 \\
\hline sangat setuju & 16 & $53,3 \%$ & 53,3 & 100,0 \\
\hline Total & 30 & 100,0 & 100,0 & \\
\hline
\end{tabular}

Sumber: Data primer yang diolah tahun 2018 diambil dari data SPSS 23

Berdasarkan data yang diatas, dapat diketahui bahwa sebagai besar responden sepakat menyatakan setuju, (sangat setuju 53,3\% )dan setuju 40,0\%, dan ragu-ragu 3,3\% dalam pengelolaan kelas.

Tabel 3

Memusatkan perhatian kelompok(X3)

\begin{tabular}{|l|c|c|r|r|}
\hline \multicolumn{1}{|c|}{ Kategori } & Frequency & Percent & \multicolumn{1}{c|}{$\begin{array}{c}\text { Valid } \\
\text { Percent }\end{array}$} & $\begin{array}{c}\text { Cumulative } \\
\text { Percent }\end{array}$ \\
\hline ragu-ragu & 1 & $3,3 \%$ & 3,4 & 3,4 \\
\hline Setuju & 6 & $20,0 \%$ & 20,7 & 24,1 \\
\hline sangat setuju & 22 & $73,3 \%$ & 75,9 & 100,0 \\
\hline Total & 30 & $100,0 \%$ & 100,0 & \\
\hline
\end{tabular}


Sumber: Data primer yang di olah tahun 2018 diambil dari data SPSS 23

Berdasarkan data yang diatas, dapat diketahui bahwa sebagai besar responden sepakat menyatakan setuju, (sangat setuju 73,3\% )dan setuju $20,0 \%$, dan ragu-ragu 3,3\% dalam pengelolaan kelas.

Tabel 4

Memberi petunjuk dan tujuan yang jelas (X4)

\begin{tabular}{|l|c|c|r|r|}
\hline \multicolumn{1}{|c|}{ Kategori } & Frequency & Percent & $\begin{array}{c}\text { Valid } \\
\text { Percent }\end{array}$ & $\begin{array}{c}\text { Cumulative } \\
\text { Percent }\end{array}$ \\
\hline ragu-ragu & 5 & $16,7 \%$ & 16,7 & 16,7 \\
\hline Setuju & 13 & $43,3 \%$ & 43,3 & 60,0 \\
\hline sangat setuju & 12 & $40,0 \%$ & 40,0 & 100,0 \\
\hline Total & 30 & 100,0 & 100,0 & \\
\hline
\end{tabular}

Sumber: Data primer yang di olah tahun 2018 diambil dari data SPSS 23

Berdasarkan data yang diatas, dapat diketahui bahwa sebagai besar responden sepakat menyatakan setuju, (sangat setuju 40,0\% )dan setuju $43,3 \%$, dan ragu-ragu $16,7 \%$ ) dalam pengelolaan kelas.

\section{Tabel 5}

Memberi teguran dan penguatan (X5)

\begin{tabular}{|l|c|c|r|r|}
\hline \multicolumn{1}{|c|}{ Kategori } & Frequency & Percent & $\begin{array}{c}\text { Valid } \\
\text { Percent }\end{array}$ & \multicolumn{1}{c|}{$\begin{array}{c}\text { Cumulative } \\
\text { Percent }\end{array}$} \\
\hline tidak setuju & 1 & $3,3 \%$ & 3,3 & 3,3 \\
\hline ragu-ragu & 1 & $3,3 \%$ & 3,3 & 6,7 \\
\hline Setuju & 12 & $40,0 \%$ & 40,0 & 46,7 \\
\hline sangat setuju & 16 & $53,3 \%$ & 53,3 & 100,0 \\
\hline Total & 30 & 100,0 & 100,0 & \\
\hline
\end{tabular}

Sumber: Data primer yang di olah tahun 2018 diambil dari data SPSS 
Berdasarkan data yang diatas, dapat diketahui bahwa sebagai besar responden sepakat menyatakan setuju, (sangat setuju 53,3\% )dan setuju 40,0\%, dan ragu-ragu 3,3\%) dalam pengelolaan kelas.

\section{b. Hasil Prestasi belajar siswa}

\section{Tabel 6}

Pemahaman siswa (Y 1)

\begin{tabular}{|l|c|c|r|r|}
\hline \multicolumn{1}{|c|}{ Kategori } & Frequency & Percent & \multicolumn{1}{c|}{$\begin{array}{c}\text { Valid } \\
\text { Percent }\end{array}$} & $\begin{array}{c}\text { Cumulative } \\
\text { Percent }\end{array}$ \\
\hline ragu-ragu & 2 & $6,7 \%$ & 6,7 & 6,7 \\
\hline Setuju & 10 & $33,3 \%$ & 33,3 & 40,0 \\
\hline sangat setuju & 18 & $60,0 \%$ & 60,0 & 100,0 \\
\hline Total & 30 & 100,0 & 100,0 & \\
\hline
\end{tabular}

Sumber: Data primer yang di olah tahun 2018 diambil dari data SPSS 23

Berdasarkan data yang diatas, dapat diketahui bahwa sebagai besar responden sepakat menyatakan setuju, (sangat setuju 60,0\% )dan setuju 33,3\%, dan ragu-ragu $6,7 \%$ dalam prestasi belajar siswa.

\section{Tabel 7}

Sikap siswa (Y2)

\begin{tabular}{|l|r|r|r|r|}
\hline \multicolumn{1}{|c|}{ Kategori } & Frequency & Percent & $\begin{array}{c}\text { Valid } \\
\text { Percent }\end{array}$ & $\begin{array}{c}\text { Cumulative } \\
\text { Percent }\end{array}$ \\
\hline sangat tidak setuju & 1 & $3,3 \%$ & 3,3 & 3,3 \\
\hline tidak setuju & 3 & $10,0 \%$ & 10,0 & 13,3 \\
\hline ragu-ragu & 10 & $33,3 \%$ & 33,3 & 46,7 \\
\hline Setuju & 10 & $33,3 \%$ & 33,3 & 80,0 \\
\hline sangat setuju & 6 & $20,0 \%$ & 20,0 & 100,0 \\
\hline Total & 30 & 100,0 & 100,0 & \\
\hline
\end{tabular}

Sumber: Data primer yang di olah tahun 2018 diambil dari data SPSS 23

Berdasarkan data yang diatas, dapat diketahui bahwa sebagai besar responden sepakat menyatakan setuju, (sangat setuju 20,0\% )dan setuju $33,3 \%$, ragu-ragu $6,7 \%$ dan tidak setuju $10,0 \%$, sangat tidak setuju $3,3 \%$ ) dalam prestasi belajar siswa. 
Tabel 8

Perilaku siswa (Y3)

\begin{tabular}{|l|c|c|r|r|}
\hline \multicolumn{1}{|c|}{ Kategori } & Frequency & Percent & \multicolumn{1}{c|}{$\begin{array}{c}\text { Valid } \\
\text { Percent }\end{array}$} & \multicolumn{1}{c|}{$\begin{array}{c}\text { Cumulative } \\
\text { Percent }\end{array}$} \\
\hline ragu-ragu & 8 & 26,7 & 26,7 & 26,7 \\
\hline Setuju & 16 & 53,3 & 53,3 & 80,0 \\
\hline sangat setuju & 6 & 20,0 & 20,0 & 100,0 \\
\hline Total & 30 & 100,0 & 100,0 & \\
\hline
\end{tabular}

Sumber: Data primer yang di olah tahun 2018 diambil dari data SPSS 23

Berdasarkan data yang diatas, dapat diketahui bahwa sebagai besar responden sepakat menyatakan setuju, (sangat setuju 20,0\% )dan setuju $53,3 \%$, ragu-26,7\% dalam prestasi belajar.

Kemudian peneliti menyajikan koefisien korelasi dan analisis regresi

Tabel 16

\section{Coefficients ${ }^{\mathrm{a}}$ Regresi}

\begin{tabular}{|c|c|c|c|c|c|}
\hline \multirow[b]{2}{*}{ Model } & \multicolumn{2}{|c|}{$\begin{array}{c}\text { Unstandardized } \\
\text { Coefficients }\end{array}$} & $\begin{array}{c}\text { Standardized } \\
\text { Coefficients } \\
\end{array}$ & & \\
\hline & $\mathrm{B}$ & Std. Error & Beta & $\mathrm{T}$ & Sig. \\
\hline $\begin{array}{l}\text { (Constant) } \\
\text { pengelolaan kelas }\end{array}$ & $\begin{array}{r}20,393 \\
, 601\end{array}$ & $\begin{array}{r}14,026 \\
, 185\end{array}$ &, 522 & $\begin{array}{l}1,454 \\
3,242\end{array}$ & $\begin{array}{l}, 157 \\
.003\end{array}$ \\
\hline
\end{tabular}

a. Dependent Variable: prestasi belajar siswa

Berdasarkan pengolahan data yang ada, maka persamaan regresi yang dapat di peroleh sebagai berikut: $Y=20,393+0,601 \mathrm{X}$, dimana $\mathrm{Y}$ $=$ Prestasi Belajar siswa, $\mathrm{X}=$ Pengelolaan Kelas keterangan sebagai berikut:

a. Konstan regresi sebesar 20,393 menyatakan bahwa prestasi belajar siswa sudah ada sekalipun tidak ada pengelolaan kelas.

b. Koefisien sebesar 0,601 menyatakan bahwa setiap perubahan $100 \%$ pengelolaan kelas akan meningkatkan prestasi belajar siswa $60,1 \%$. Sebaliknya, bila pengelolaan kelas turun $100 \%$, maka prestasi belajar siswa juga diprediksi mengalami penurunan sebanyak $60,1 \%$. Jadi tanda + menyatakan arah hubungan yang searah, yaitu kenaikan atau penurunan variabel independen (X) akan mengakibatkan kenaikan atau penurunan variabel dependen $(\mathrm{Y})$. 


\section{Analisis Korelasi Sederhana}

Analisis korelasi "dilakukan untuk mengetahui hubungan antara variabel terikat dengan variabel bebas dan sebaliknya. Pengaruh variabel $\mathrm{X}$ dan $\mathrm{Y}$ bersifat positif, artinya jika $\mathrm{X}$ turun maka $\mathrm{Y}$ naik. Pengaruh negatif, artinya jika X naik, maka Y turun."19 Untuk melakukan perhitungan korelasi penelitian peneliti menggunakan IBM SPSS Statistik 23 untuk metode korelasi regresi sederhana. Berikut output dari uji korelasi:

Tabel 17

Correlations

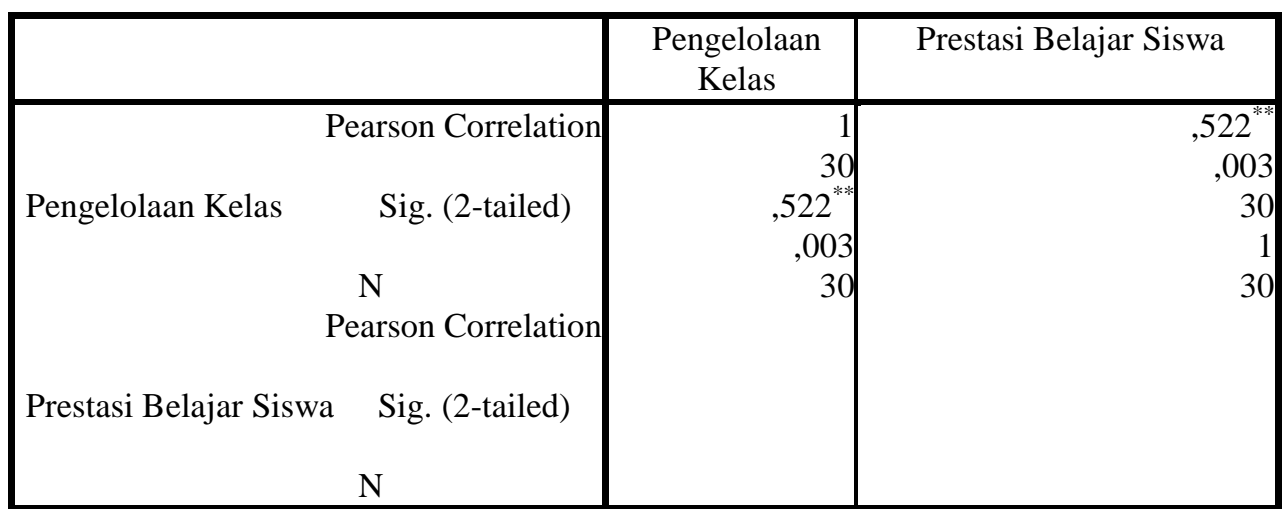

** Correlation is significant at the 0.01 level (2-tailed).

Penjelasan dari output di atas adalah terlihata bahwa koefisien besarnya pengaruh antara variabel pengelolaan kelas dengan prestasi belajar siswa yang di hitung dengan koefisien korelasi adalah 0, 522 . Untuk mengetahui besarnya pengaruh anatara variabel tersebut harus memiliki standar pengukuran. Sukamto dalam bukunya menjelaskan : “ Adalah kesepakatan bahwa derajat besar hubungan antara dua variabel itu (koefisien) selalu diukur dengan hasil di nyatakan dalam lambang bilangan antara 0,00 (tidak ada hubungan antara variabel) dan 1,00 atau -

${ }^{19}$ Sahid Raharjo. Uji korelasi dengan program online: htt://www.konsistensi.com, Diakses 20 april 2018. 
1,00 (ada hubungan). ${ }^{, 20}$ Arti derajat besarnya pengaruh dapat dilihat dalam tabel berikut:

Tabel 18.

Interval Koefisien Korelasi

\begin{tabular}{|c|l|}
\hline Interval Koefisien & Tingkat Hubungan \\
\hline $0,80-1,00$ & Sangat kuat \\
\hline $0,60-0,799$ & Kuat \\
\hline $0,40-0,599$ & Sedang \\
\hline $0,20-0399$ & Rendah \\
\hline $0,00-0,199$ & Sangat rendah \\
\hline
\end{tabular}

Berdasarkan tabel 16, maka dapat diketahui besar pengaruh antara kedua variabel $(\mathrm{X})$ dan $(\mathrm{Y})$ adalah 0,522. Berdasarkan tabel di atas menunjukkan adanya pengaruh yang sedang antara kedua variable tersebut. Hal itu dapat dilihat dari hasil yang positif (tidak ada tanda negatif pada angka0, 522), dengan demikian hal ini menunjukkan semakin besar pengelolaan kelas maka prestasi belajar siswa akan semakin meningkat.

\section{Koefisien Determinasi}

Penjelasan tabel 20 adalah angka $\mathrm{R}$ square adalah $0,522 \times 0,522=$ $0,273)$. R Square bisa di sebut koefisien determinasi, yang berarti $27 \%$ prestasi belajar siswa di pengaruhi oeleh pengelolaan kelas. sisanya $(100 \%-27 \%=73 \%)$, hal tersebut menunjukkan ada faktor lain yang mempengaruhi prestasi belajar siswa.

Tabel 19

Model Summary

\begin{tabular}{|c|c|c|c|c|}
\hline Model & $\mathrm{R}$ & R Square & $\begin{array}{l}\text { Adjusted R } \\
\text { Square }\end{array}$ & $\begin{array}{l}\text { Std. Error of the } \\
\text { Estimate }\end{array}$ \\
\hline 1 &, $522^{\mathrm{a}}$ &, 273 & ,247 & 5,230 \\
\hline
\end{tabular}

${ }^{20}$ Ibid., 
Berdasarkan tabel $\mathrm{R}$ (Korelasi) di atas tampak bahwa nilai $\mathrm{R}^{2}=0$, 273 artinya konstribusi variabel bebas X terhadap Y sebesar 27,3\%. Hasil perhitungan regresi dapat diketahui bahwa koefisien determinasi (adjusted $\mathrm{R}^{2}$ ) yang diperoleh sebesar 0,273. Hal ini berarti 27,3\% variabel prestasi belajar siswa dapat dijelaskan oleh variabel pengaruh tentang pengelolaan kelas (X), selanjutnya sisanya sebesar $73 \%$ diterangkan oleh variabel lain yang tidak diajukan dalam penelitian ini.

\section{Kesimpulan}

Berdasarkan hasil penelitian dengan menggunakan langkahlangkah analisis data yang telah dilaksanakan oleh peneliti, maka peneliti dapat menyimpulkan: berdasarkan hasil penelitian bahwa persamaan regresi yang yang di dapat adalah $\mathrm{Y}=20,393+0,601 \mathrm{X}$, dimana: $\mathrm{Y}=$ prestasi belajar siswa, $\mathrm{X}=$ pengaruh pengelolaan kelas. Artinya koefisien regresi sebesar 0, 601 atau 60,1\% menyatakan bahwa setiap perubahan Pengelolaan kelasakan meningkatkan Prestasi Belajar Siswa di Sekolah Menengah Pertama Kanaan Ungaran sebesar 60,1\%. Sebaliknya, bila pengelolaan kelas $100 \%$, maka prestasi belajar siswa juga diprediksikan mengalami penurunan sebesar $60,1 \%$.

Berdasarkan hasil penelitian besarnya koefisien korelasi pengaruh antara kedua variabel adalah 0,522 . Artinya tingkat pengaruh menunjukkan adanya hubungan yang sedang antara variabel $\mathrm{X}$ terhadap variabel Y. Ada hubungannya adalah positif, sebab pada angkat 0,522 tidak ada tanda negatif. Oleh karena itu, bahwa dapat diartikan bahwa semakin besar pengelolaan kelas, maka semakin meningkat prestasi belajar siswa.

Hal ini juga diperkuat dari hasil uji hipotesis yang menunjukkan bahwa $\mathrm{H}_{0}$ ditolak dan $\mathrm{H}_{1}$ diterima. Artinya ada pengaruh positif yang signifikan antara pengelolaan kelas terhadap prestasi belajar siswa. berdasarkan hasil penelitian bahwa hasil dari koefisien diterima melalui perhitungan SPSS 23 menghasilkan 27\%, pengelolaan kelas memberikan sumbangan $27 \%$ kepada prestasi belajar siswa sedangkan sisanya $(100 \%$ $-27,3 \%=72,7 \%$ dipengaruhi oleh faktor yang lain. 


\section{Kepustkaan}

Abubakar, Sitti, Rahmaniar. 2007. Belajar dan Pembelajaran. Kendari: UNHALU.

Anurahman. 1995. Belajar dan Pembelajaran . Jakarta: Kedokteran EGC, 1995.

Bahari Djamarah, Syaiful dan Aswan Zain. 2006. Strategi Belajar Mengajar . Jakarta : Rineka Cipta.

Dimyati dan Mudjiono. 2006. Belajar dan Pembelajaran .Jakarta: Rineka Cipta.

E.G. Homrighausen, E.G \& Enklaar. 1985. Pendidikan Agama Kristen Jakarta: BPK Gunung Mulia.

Iskandar. 2009. Psikologi Pendidikan. Ciputat: Gaung Persada.

Lilik Kristanto, Paulus. 2010. Prinsip dan Praktek Pendidikan Agama Kristen. Yogyakarta : Andi Offset.

Semiawan, Cony. 1990. Pendekatan Keterampilan Proses. Jakarta: Gramedia, 1990.

Raharjo, Sahid. Uji Korelasi dengan Program Online: htt://www.konsistensi.com. Diakses 20 April 2018

N.A. Ametembun. 1987. Pendidikan Kurikulum Program Pengajaran Efek Intruksional dan Pengiring CBSA Metode Mengajar Media Pendidikan Pengelolaan Kelas dan Evaluasi Hasil Belajar Bandung: Remaja Karya.

Nata, Abdin. 2009. Prespektif Islam Tentang Strategi Pembelajaran .Jakarta: Prenada Media Group.

Slameto. 1988. Belajar dan Faktor-Faktor yang Mempengaruhinya .Jakarta: Bina Aksara.

http://belajar psikologi.com/pengertian-belajar-menurut-ahli Diakses di Ungaran 23 Mei 2018.

Saroni, Muhammad. 2006. Manajemen Sekolah-Kiat Menjadi Pendidik yang Kompeten. Jakarta: Ar-Ruzz. 